\title{
ÉDOUARD GLISSANT E J OÃO GUIMARÃES ROSA: ENCONTRO DE ESCRITAS, LINHAS DE FUGA
}

\author{
Henrique de Toledo Groke
}

\begin{abstract}
RESUMO
Trata-se aqui de uma aproximação entre noçóes desenvolvidas pelo filósofo martinicano Édouard Glissant (1928-2011) em alguns de seus ensaios e o romance Grande sertão: veredas (1956) de João Guimarães Rosa (1908-1967), escritor brasileiro. Pretendi identificar algumas ressonâncias entre a escrita de ambos considerando as extrapolaçóes de seus gêneros "originais", ficção e ensaio, e como imbricam ética e estética.
\end{abstract}

PALAVRAS-CHAVE: Édouard Glissant, João Guimarães Rosa, poéticas de escritura.

La porte de la mer, violette et bleue et violette, relève d'une seule vague ce que la noire profondeur grandissante aménage peu à peu, et cette vive alliance de la lumière et de l'obscurité, ils m'ont alloué l'éclat, et j'habitais l'obscur, et puis cette frappe d'une lame baroque et difficile et grenue, ses élancements se relaient comme de la trame d'un texte. ${ }^{1}$

1 "A porta do mar, violeta e azul e violeta, eleva em apenas uma onda o que a profundeza negra e crescente agrega aos poucos, e esta viva aliança entre a luz e a escuridão, concederam-me o brilho, e eu habitava o obscuro, e então esta investida de uma lâmina barroca e difícil e granulosa, seus impulsos se revezam como na trama de um texto" [Tradução livre de minha autoria. Assim procederei sempre que houver o uso de citação no original em francês.] GLISSANT, É. Une nouvelle région du monde. Paris: Gallimard, 2006, p. 11. 


\section{Sobre o que pulsa e aflora do texto}

artamos da imagem sugerida por Édouard Glissant na epígrafe. O mar em seu encontro com a terra, a vinda à tona da onda repentina trazendo à superfície o que já estava ali em alguma profundeza, em maturação, sem que este desvelamento signifique apenas iluminação, mas nuance na cor, um dar à luz e à escuridão - as investidas sucessivas de uma lâmina barroca e áspera: tal é o movimento visto por Glissant no texto, a começar pelo seu próprio, animando o que poderíamos chamar ensaio poético. Em se tratando de linguagem - forma mediadora de sentido - tudo se implica sem pureza, a não ser aquela que se idealiza como paradoxo, posto que, no contexto das produçóes de Édouard Glissant e João Guimarães Rosa, se está ciente da inextricável rede de relações do convívio humano, aí incluídas suas invenções e intervenções no mundo.

\section{A imprescindível fuga}

Insistindo momentaneamente na imagem movimentada por Glissant para que ela permaneça pulsando, gostaria de fazer confluir a noção de "linha de fuga” formulada por Gilles Deleuze e Félix Guattari em "Introdução: Rizoma”, em que abordam o "rizoma" como imagem alternativa aos sistemas de pensamento centralizadores, sendo estes aproximados à imagem da "raiz". A "linha de fuga" é uma noção operacional retomada muitas vezes em outros capítulos de Mil platôs, mas é nesta introdução que é tocada primeiramente:

Um livro não tem objeto nem sujeito; é feito de matérias diferentemente formadas, de datas e velocidades muito diferentes. Desde que se atribui um livro a um sujeito, negligencia-se este trabalho das matérias e a exterioridade de suas correlaçóes. Fabrica-se um bom Deus para movimentos geológicos. Num livro, como em qualquer coisa, há linhas de articulação ou segmentaridade, estratos, territorialidades, mas também linhas de fuga, movimentos de desterritorialização e desestratificação. ${ }^{2}$

2 DElEUZE, G.; GUATTARI, F. “Introdução: Rizoma”. Mil Platôs (vol.1). Trad. A. Guerra Neto e C. P. Costa. São Paulo: Ed. 34, 1995, p. 11, realce meu. 
Referindo-se aos livros, mas também a qualquer coisa, os autores notam uma conjunção de movimentos ordenadores e desordenadores que vão em busca de possibilidades e variantes combinatórias, muito em confluência à imagem da epígrafe. As linhas de fuga, igualmente presentes em discursos pretensos a universalismos, nos quais se encontram enclausuradas, e em discursos propensos ao intercâmbio, em que são tomadas como principal elemento animador, estas linhas de fuga consistem nas tensóes ou elementos que apontam a relação do livro, no caso, com as exterioridades e alimentam o consequente movimento reativo em sua dinâmica interna.

Isto é, da mesma forma que possibilitam a conexão do texto a elementos externos, são intervençóes latentes porque o movimento ao exterior traz novas codificaçóes aos elementos internos. Como projeções, são lacunas que, a partir do texto, retornam a ele como incidências, falando dele e de si mesmas. Movimento espiralado, desensimesmado, pois busca (1) a prospecção do que está no que talvez seja profundeza, inacessível diretamente e enquanto tal, (2) o garimpo da superfície, tão arriscado à deterioração desta mesma superfície, e (3) a inspiração e expiração sucessivas do que se move na atmosfera circundante. Tal movimento é possibilitado pela natureza mediadora da linguagem ativada pela leitura. Por mais que se tente fixar ortografias e sentidos, significantes e significados, esta natureza mediadora e potencialmente poética da linguagem tende sempre a redefinir não só seus objetos, mas seus sujeitos, aqueles que dela se utilizam sem nunca poder de fato detê-la.

\section{Do mesmo ao diverso}

As imagens de texto comentadas e as implicações de sua prática estão presentes em Glissant. Ele elabora sua escrita distanciando-se da organização racionalista e linear do discurso teórico e de seu respectivo modo de interpretação da realidade, assim como se afasta de possíveis relaçôes a gêneros sacralizantes ou ufanistas. Para ele, a linguagem é o principal elemento pelo qual se articula a relação com o mundo e assim confunde-se com o ato em seu aspecto político, pois este ato se formula e se questiona a partir do uso consciente e refletido da expressáo: 
La parole poétique en jeu dans l'esthétique d'Édouard Glissant ne ressort pas du psaume ni de l'hymne mais d'un souffle traversé de cris: sa scansion alterne le cri comme expression inarticulée, et le cri comme annonce, effusion, événement que le poète dit à la criée. ${ }^{3}$

Os diversos aspectos de imbricação entre a forma de escrita e o conteúdo do pensamento glissantianos manifestam-se como reação às diversas violências (físicas, simbólicas, morais) fundadoras do colonialismo. Glissant apropria-se voluntária e conscientemente de dinâmicas culturais que notou nas sociedades americanas pós-coloniais para formular as poéticas da Relação e do Diverso.

Poética é aqui entendida como prática distanciada de qualquer norma prescritiva e refere-se a posturas e fazeres estéticos particulares que não pretendem estabelecer-se como padrão. Mesmo inicialmente particulares, essas poéticas mostram-se abertas e apontam inúmeras linhas de fuga. Entre as dinâmicas de que Glissant se apropria encontram-se o pensamento do vestígio, a repetição, a acumulação enquanto inventário anárquico do real, a crioulização e a noção de opacidade. Embora sua concepção parta da observação do contexto antilhano, tais noçóes ampliaram-se à análise de dinâmicas presentes nas relaçóes humanas de modo geral, extrapolando os contextos especificamente coloniais.

Principiando pela crioulização - termo baseado no fenômeno das línguas crioulas, em que, diferentemente da mestiçagem, o principal aspecto é a imprevisibilidade do resultado do choque entre elementos culturais distantes - , temos:

O que acontece no Caribe durante três séculos é, literalmente, o seguinte: um encontro de elementos culturais vindos de horizontes absolutamente diversos e que realmente se crioulizam, realmente se imbricam e se confundem um no outro para dar

3 "A fala poética em jogo na estética de Édouard Glissant não se origina do salmo nem do hino, mas de um fôlego atravessado por gritos: sua escansáo alterna o grito como expressão inarticulada e o grito como anúncio, efusão, acontecimento que o poeta diz aos gritos". NOUDELMANN, F. “Glissant le déchiffreur”. Littérature, 154: 36-42, Paris, jun. 2009, p. 41, itálico do autor. 
nascimento a algo absolutamente imprevisível, absolutamente novo - a realidade crioula. [...] a crioulização que se dá na Neo-America ${ }^{4}$ e que se estende pelas outras Américas é a mesma que vem acontecendo no mundo inteiro. ${ }^{5}$

O principal catalisador deste processo e para quem o choque cultural é mais radical e dramático são os negros traficados como escravos do continente africano para as diversas colônias americanas. Sua situação difere da de outros migrantes a começar pelo fato de terem sido trazidos à força. A isto se somam simultaneamente três depossessóes ${ }^{6}$ cruciais: linguistica, visto que uma das medidas para minimizar a articulação de rebelióes durante o transporte no navio negreiro foi misturar o máximo possível os indivíduos de diferentes línguas para dificultar a comunicação; espacial, pois foram tirados de sua terra e tornados cativos em outra muito distante, com a qual teriam a princípio apenas vínculos de opressão e estranhamento; e histórica, no momento em que seu passado e sua voz enquanto sujeitos históricos foram abafados e subordinados a seus dominadores. Glissant os chama de migrantes nus:

[...] o africano deportado não teve a possibilidade de manter, de conservar essa espécie de heranças pontuais. Mas criou algo imprevisível a partir unicamente dos poderes da memória, isto é, somente a partir dos pensamentos do rastro/resíduo ${ }^{7}$, que lhe restavam: compôs linguagens crioulas e formas de arte válidas para todos, como por exemplo a música de jazz, que é

4 Neo-América, Meso-América e Euro-América, absolutamente não estanques, são as três denominações de Glissant às diferentes formações identitárias e culturais presentes nas regiôes americanas, resultantes das diferentes composiçóes de povoamento e seu desenvolvimento histórico.

5 GLISSANT, É. Introdução a uma Poética da Diversidade. Trad. E. A. Rocha. Juiz de Fora: Ed. UFJF, 2005, p. 17-8. Registro aqui minha discordância em relação à tradução do título original, Introduction à une Poétique du Divers, que seria mais adequadamente traduzido para Introdução a uma Poética do Diverso.

6 DAMATO, D. B. Édouard Glissant: Poética e Política. São Paulo: Annablume, 1996.

$7 \mathrm{Na}$ tradução brasileira optou-se pelo conjunto dos termos rastro/resíduo, enquanto que preferi traduzir a expressão pensée de la trace por pensamento do vestígio por considerá-la mais adequada e suficiente. Esta opção será utilizada quando fora das citaçóes da tradução publicada. 
re-constituída com a ajuda de instrumentos por eles adotados, mas a partir de rastros/resíduos de ritmos africanos fundamentais. Embora esse neo-americano não cante canções africanas que datam de dois ou três séculos, ele re-instaura no Caribe, no Brasil e na América do Norte, através do pensamento do rastro/resíduo, formas de arte que propóe como válidas para todos. O pensamento do rastro/resíduo me parece constituir uma dimensão nova daquilo que é necessário opormos, na situação atual do mundo, ao que chamo de pensamentos de sistema ou sistemas de pensamento. Os pensamentos de sistema ou os sistemas de pensamento foram prodigiosamente fecundos, prodigiosamente conquistadores e prodigiosamente mortais. $\mathrm{O}$ pensamento do rastro/resíduo é aquele que se aplica, em nossos dias, da forma mais válida, à falsa universalidade dos pensamentos de sistema. ${ }^{8}$

Esta reformulação das identidades individuais e coletivas e suas formas de expressão articula-se como um pensamento do vestígio, pois faz interagir elementos da nova realidade com os vestígios do que eram imaginários estabelecidos no cotidiano anterior, agora destroçados. Ao contrário da postura que criou a situação de violência, o principal aspecto salientado deste pensamento é a aceitação, ao menos inconsciente, da coexistência dos elementos ora presentes e da prática de sua mescla e combinação. A oposição destas duas formas de pensamento e comportamento é assim colocada:

Le Même, qui n'est pas l'uniforme ni le stérile, ponctue l'effort de l'esprit humain vers cette transcendance d'un humanisme universel sublimant les particuliers (nationaux). [...] Mais, pour nourrir sa prétention à l'universel, le Même a requis (a eu besoin de) la chair du monde. L'autre est sa tentation. Non pas encore l'Autre comme projet d'accord, mais l'autre comme matière à sublimer $[. .$.$] .$

8 GLISSANT, É. Introdução a uma Poética da Diversidade, op. cit., p. 20. 
Le Divers, qui n'est pas le chaotique ni le stérile, signifie l'effort de l'esprit humain vers une relation transversale, sans transcendance universaliste. Le Divers a besoin de la présence des peuples, non plus comme objet à sublimer, mais comme projet à mettre en relation. ${ }^{9}$

A recusa de hierarquização de qualquer tipo por parte do Diverso relaciona-se à acumulaçáo - urgente nos primeiros momentos de uma reformulação identitária - e à necessidade do respeito à opacidade alheia, em contrapartida à ânsia por transparência presente nas atitudes de assimilação do Outro, característica do Mesmo:

Si nous examinons le processus de la "compréhension" des êtres et des idées dans la perspective de la pensée occidentale, nous retrouvons à son principe l'exigence de cette transparence. Pour pouvoir te "comprendre" et donc t'accepter, il me faut ramener ton épaisseur à ce barème idéel qui me fournit motif à comparaisons et peut-être à jugements. Il me faut réduire. ${ }^{10}$

Para que esta redução não ocorra, a opacidade deve ser percebida e respeitada. Ao contrário do que se pode pensar, sua aceitação como característica de todos os seres e ideias não resulta na impossibilidade de relação, apenas a problematiza, justamente por ressaltá-la. A questão é não pretender compre-

9 "O Mesmo, que não é o uniforme nem o estéril, pontua o esforço do espírito humano em direção a esta transcendência de um humanismo universal que sublima os particulares [...]. Mas, para alimentar sua pretensão ao universal, o Mesmo solicitou (teve necessidade de) a carne do mundo. O outro é sua tentação. Não ainda o Outro como projeto de acordo, mas o outro como matéria a sublimar [...]. / O Diverso, que não é o caótico nem o estéril, significa o esforço do espírito humano em direção a uma relação transversal, sem transcendência universalista. O Diverso necessita da presença dos povos, não mais como objeto a sublimar, mas como projeto a colocar em relação”. GLISSANT, É. Le discours antillais. Paris: Seuil, 1981, p. 190, realce meu.

10 “Se examinarmos o processo da 'compreensão' dos seres e das ideias na perspectiva do pensamento ocidental, reencontraremos em seu princípio a exigência desta transparência. Para poder 'compreender-te' e entâo aceitar-te, preciso levar tua densidade à escala ideal que me fornece elementos para comparaçóes e talvez julgamentos. Eu preciso reduzir". GLISSANT, É. Poétique de la relation. Paris: Gallimard, 1990, p. 204. 
ender totalmente seu interlocutor ou objeto, pois esta totalização é impossível sem redução e consequente violência em algum nível.

Algo importante a evidenciar nesta oposição entre Mesmo e Diverso é que ela não se dá pela simples inversão de valoraçóes negativas por positivas. Trata-se antes da desmontagem de um sistema de pensamento para dissolver suas hierarquizaçóes, tal como a oposição entre o rizoma e a raiz (associáveis a identidades, discursos, obras etc.) formulada por Deleuze e Guattari ${ }^{11}$. A comparação pretende ressaltar no esquema arbóreo (ou raiz) a existência de um núcleo gerador em que todas as relaçóes e funçóes estão predefinidas antes mesmo de seu surgimento, já no estado de semente. Em contrapartida, o rizoma escapa a estas centralização e hierarquização implícitas, pois cresce e se organiza sem predeterminaçóes, respondendo aos diversos contextos em que se encontrará.

Alguns dos princípios de funcionamento do rizoma são: princípio de conexão e heterogeneidade - suas funções não são fixas, mas comutáveis e redefinidas a cada momento, um devir constante constituído de "estares"; princípio de multiplicidade - o rizoma não é apreensível como conjunto de indivíduos ou unidades e sim como multiplicidade em si, isto é, o próprio múltiplo tratado como substantivo, desligado de toda relação com o Uno; e princípio de ruptura a-significante - referindo-se à impossibilidade de esquadrinhamento ou tentativa de significação por um recorte que pretenda limitá-lo ${ }^{12}$. O Diverso pressupõe relação rizomática, enquanto o Mesmo baseia-se no Uno-raiz, pretendendo-se entidade central.

Assimilados à organização arbórea encontra-se o que Glissant chama "absolutos da escrita", "absolutos" que se referem à pouca ou nenhuma flexibilidade desta "escrita" e aos sistemas prescritivos que a regem, técnica e socialmente. Em resposta a esta rigidez, na mesma intenção de diluir o centro pelas periferias, a valorização da oralidade soma-se aos procedimentos abarcados pelas poéticas do Diverso e da Relação:

Enfin, nous ne devons peut-être pas oublier que nous pouvons servir à la conjonction complexe de l'écriture et de l'oralité; apporter ainsi notre part à l'expression d'un homme nouveau, libéré des

11 DELEUZE, G.; GUATTARI, F. “Introdução: Rizoma”. Mil Platôs (vol. 1), op. cit., p. 13-5.

12 Idem, p. 15-21. 
absolus de l'écrit et en prise sur une audience nouvelle de la voix.

[...] L'invasion des barbares est pourtant nécessaire, c'est par elle que le rééquilibrage des valeurs se pratique: l'affirmation dans le réel de l'égale dignité des composantes d'une culture. [...] L'écrit s'oralise. La "littérature" récupère de la sorte un "réel" qui semblait la contraindre et la limiter. ${ }^{13}$

Esta recuperação de uma dimensão mais ampla do real corresponde, como dito, à dissolução dos centros ditadores de padróes e procura vislumbrar algo diferente da disputa de poder entre as perspectivas universalizantes do real:

Le deuxième projet littéraire que j'ai [...] c'est justement cette inscription dans une relation mondiale parce que nous sommes tout à fait portés d'instinct à nous inscrire dans cette dimension, pour une raison bien simple: nous n’avons jamais régenté le monde, nous n'avons jamais dominé le monde, nous n’avons jamais conduit le monde et par conséquent nous sommes portés d'instinct à nous concevoir dans le monde avec les autres, au même niveau que les autres, ce qui est déjà une des premières conditions de la poétique de la relation. ${ }^{14}$

13 "Enfim, não devemos talvez esquecer que podemos servir à conjunção complexa entre escrita e oralidade; levar assim nossa parte à expressão de um novo homem, liberto dos absolutos da escrita e aberto a uma nova audiência da voz. / [...] A invasão dos bárbaros é no entanto necessária; é por meio dela que o reequilíbrio dos valores se pratica: a afirmação na realidade da igual dignidade dos componentes de uma cultura. [...] A escrita se oraliza. A 'literatura' recupera assim um 'real' que parecia restringi-la e limitá-la”. GLISSANT, É. Le discours antillais, op. cit., p. 200-1, realce meu.

14 “O segundo projeto literário que tenho [...] é justamente esta inscrição numa relação mundial, posto que somos efetiva e instintivamente levados a nos inscrever nesta dimensão por uma razão bastante simples: jamais regemos o mundo, jamais dominamos o mundo, jamais conduzimos o mundo e consequentemente somos instintivamente levados a nos conceber no mundo com os outros, no mesmo nível que os outros, o que já é uma das primeiras condiçóes da poética da relação." GLISSANT, É. "Propos recueillis par D. Laferrière". Étincelles. Montréal, abr./mai., 1983, p. 87 apud DAMATO, D. B. Édouard Glissant: Poética e Politica, op. cit., p. 275. 
A poética da Relação apenas é possível a partir do esforço de ação e pensamento em direção ao Diverso, ou seja, uma poética como pré-requisito para a possibilidade de prática da outra. Estas poéticas podem operar tanto na formulação quanto na apreensão de discursos filosóficos e artísticos e possibilitam a conscientização sobre seu caráter de constructo, pois se formaram na necessidade de desconstrução dos sistemas de pensamento, sondando suas falhas dissimuladas.

\section{Metadiscurso avaliativo e discurso como ato}

No pequeno comentário de abertura à primeira conferência de Introduction à une Poétique du Divers (1995), Glissant coloca o seguinte a respeito da forma e conteúdo dos textos ali presentes: "O objeto destas quatro conferências parecerá complexo e errático, e é provável que ao longo desta exposição eu venha a retomar temas que se entrelaçarão, temas que se repetirão e, antecipadamente, peço desculpas, mas essa é a minha maneira de trabalhar." ${ }^{15}$

Além da brevíssima autoavaliação de Glissant, o trecho é interessante pela ironia do pedido de desculpas justamente por uma característica intencional de sua estratégia discursiva e que está presente em toda a sua produção ensaística: a errância estrutural e nocional. Esta ironia, resultante de um tateamento no trato com o leitor no trecho citado, talvez fosse notada apenas por quem já tivesse algum contato com seus textos, não fosse a presença de um prólogo anterior de abertura em que o autor lamenta justamente não poder exercer seu estilo mais livremente:

O texto destas quatro conferências [...] padece, sem dúvida, de um excesso de "teoria", ao passo que teria sido melhor abordar o Diverso e os entrelaçamentos do "Todo-o-mundo" através de um fluxo de abordagens poéticas, de descriçôes de paisagens e situaçóes, de um jogo ecoando harmonias e desarmonias, que dessem conta do nosso "sendo-no-mundo", comum a todos. Mas a regra, neste caso, é tentar dizer o máximo possível no lapso de tempo que nos é concedido, e abordar, se náo o que

15 GLISSANT, É. Introdução a uma Poética da Diversidade, op. cit., p. 13. 
nos parece mais claro, pelo menos o que parece mais imediatamente probante.

Trata-se de um trabalho construído de um só fôlego, em que a fala predomina quase sempre sobre as reservas da escrita, e em que o "eu" se manifesta exageradamente, mais ainda porque as entrevistas que se seguem às conferências reforçam, obviamente, o engajamento e a tomada de posição. Espero que após a leitura prevalecerá o sentimento de uma pesquisa - talvez inquieta ou errante - e não de um sistema fechado em si mesmo. ${ }^{16}$

A tentativa de preparação do leitor é explicável por se tratar de texto que se quer introdutório, informação implícita no trecho acima e explícita no título, mas o alerta de Glissant reproduzido anteriormente talvez seja o que ali há de mais introdutório. Embora note-se de fato o estabelecimento de linhas de raciocínio mais explicativas, a dinâmica textual desta Introduction à une Poétique du Divers ainda é muito próxima de seu hábito, um discurso em espiral ${ }^{17}$. Esta imagem ilustra sua estratégia discursiva - contaminada voluntariamente pelo descrito até aqui - que se dá pela passagem por noçóes - termo mais flexível que conceito - diversas vezes em profundidades diferentes. "[Ses] essais, depuis [...] Soleil de la conscience [... ${ }^{18}$ paru en 1956 jusqu'à Philosophie de la relation [2009] ${ }^{19}$ n'ont cessé de reformuler une poétique de l'identité-nomade" 20 . Ou seja, a cada retomada de um tema ou aspecto em seus ensaios, o ponto de partida e o desenvolvimento da abordagem são diferentes

16 Idem, p. 7.

17 Noção empregada por Glissant em alguns textos, como no seguinte trecho: "L'imaginaire d'abord. Il travaille en spirale: d'une circulation à l'autre il rencontre de nouveaux espaces qu'il ne transforme pas en profondeurs ni en conquêtes." ["O imaginário primeiramente. Ele trabalha em espiral: de uma circulação à outra ele encontra novos espaços que ele não transforma em profundidades nem em conquistas.”]. GLISSANT, É. Poétique de la relation, op. cit., p. 216, realce meu.

18 GLISSANT, É. Soleil de la conscience. Paris: Seuil, 1956.

19 GLISSANT, É. Philosophie de la relation. Paris, Gallimard, 2009.

20 "[Seus] ensaios, desde Soleil de la conscience [...] publicado em 1956 a Philosophie de la relation [2009] não cessaram de reformular uma poética da identidade-nômade." NOUDELMANN, F. "Glissant le déchiffreur", op. cit., p. 36. 
em função das circunstâncias textuais e das linhas de fuga a se formar. Sobre Le discours antillais $(1981)^{21}$, temos:

À mon avis Le discours [antillais] est une somme archéologique tellement vertigineuse qu'un lecteur ou une lectrice, seul, ne saurait l'épuiser avec satisfaction. Il y a croisements, entre-croisements, de l'Histoire, de la littérature, de la poétique, de la sociologie, de l'économie, de la politique. Cet entrecroisement est tellement complexe que toute lecture linéaire est certainement vouée à l'échec. ${ }^{22}$

É provável que uma leitura linear que procure dominar toda a trama e desdobramentos do texto se afogue, mesmo porque não é esta a leitura que o autor quer estimular. Seus ensaios por certo expóem teorias e noçóes, mas não o fazem objetivando esgotamento nem o fazem de modo sistematizado em direção a cristalizaçóes. Antes, procuram exercer as posturas defendidas. Sua perspectiva é poética pois se evade do ensaio científico e filosófico para narrar ficçóes, causar deslocamentos de leitura, construir imagens, metáforas e alegorias tomando o quanto puder a linguagem como ato e não apenas sua função instrumental e descritiva.

Não só então a escrita é errática, tateante e cumulativa, como a leitura mais ressonante - crítica ou não - dar-se-á da mesma forma, o que, na experiência, resulta na multiplicação dos percursos possíveis. Só poderá dar-se assim pois, como dito, uma leitura ordenadora forçosamente desrespeitará a dinâmica do texto, reduzirá seu alcance e empobrecerá suas linhas de fuga, se não as podar completamente.

21 GLISSANT, É. Le discours antillais, op. cit.

22 "Em minha opinião, $O$ discurso [antilhano] é uma soma arqueológica tão vertiginosa que um leitor ou uma leitora, só, não saberia esgotá-lo com satisfação. Há nele cruzamentos, entrecruzamentos, da História, da literatura, da poética, da sociologia, da economia, da política. Este entrecruzamento é tão complexo que qualquer leitura linear está certamente fadada ao fracasso." "Dossier sur Édouard Glissant et Le discours antillais". Étincelles, Montréal, 4, 1983, p. 16 apud DAMATO, D. B. Édouard Glissant: Poética e Politica, op. cit., 1996, p. 19. 


\section{Convite ao diálogo}

Tais consideraçóes sobre o texto glissantiano e seu aspecto espiralado, tateante e cultivador de linhas de fuga poderiam muito ser reditas sobre o texto de João Guimarães Rosa que se quer abordar, Grande sertão: veredas ${ }^{23}$. Proponho então a abordagem de alguns aspectos deste romance brasileiro que me parecem dialogar com o que foi até aqui abordado sobre a escrita de Édouard Glissant, observando e levando em conta, todavia, que se trata então, de um lado, de literatura de ficção e, de outro, do chamado "ensaio poético".

Nas tensōes desta aproximação, é oportuno trazer alguma discussão sobre as relaçôes entre filosofia e literatura. Em "As formas literárias da filosofia” 24 , Jeanne Marie Gagnebin faz colocações que podem bem catalisar as reações aqui vislumbradas entre Glissant e Rosa e, mais, repercutir no que será retomado como possível interação de suas escritas ao final deste artigo. Em seu texto, Gagnebin não procura tecnicamente avaliar as diferenças para esquadrinhar os discursos filosóficos e literários e definir seus domínios de ação e direitos de alcance, mas antes considera as transformaçôes históricas de suas formas e conteúdos, de suas funções, acompanhadas que estão, estas transformações, das oscilações de definição de filosofia e literatura.

Assim, a autora questiona a parcialidade de certa perspectiva que vê a literatura como beletrismo carente de carga filosófica para alcançar alguma relevância e, noutro extremo, a filosofia como prática intelectual elitizada, despreocupada da forma, ou melhor, que veria na forma um instrumento racionalizado e talhado de modo a expressar escorreitamente o quisto ou intencionado. Por meio de uma breve análise histórica das formas literárias da filosofia, a autora defende que suas variaçôes e exploraçóes, enquanto formas mediadoras, compartilham intrinsecamente da pesquisa e exposição filosóficas,

este estranho exercício em torno de algumas questôes e de alguns conceitos, sempre retomados e recolocados, sempre deslocados e reinventados. [...] A multiplicidade das formas literárias

23 ROSA, J. G. Grande sertão: veredas. 9 ed. Rio de Janeiro: José Olympio, 1974.

24 GAGNEBIN, J. M. "As formas literárias da filosofia”. Lembrar escrever esquecer. São Paulo: Ed. 34, 2006. 
em filosofia também assinala as diversas tentativas filosóficas de abordar aquilo que excede a linguagem discursiva racional. ${ }^{25}$

As constatadas retomadas, recolocações, deslocamentos e reinvençóes desenham novamente o movimento espiral, evidenciam e convidam, na discussão focada nas formas literárias da filosofia, ao diálogo entre literatura e filosofia. Sobre isto, Gagnebin conclui:

Algumas formas literárias bastante fortes da filosofia contemporânea como o ensaio, o aforismo, o fragmento tentam, em oposição crítica à concepção totalizante dos grandes sistemas clássicos, tematizar na própria exposição, na própria apresentação do pensamento, este real que só se mostra [...] quando se desenha a figura de sua ausência. Ali, neste lugar paradoxal, nesta figuração da ausência, filosofia e literatura contemporâneas, com todas as suas diferenças, certamente se encontram. ${ }^{26}$

Passemos então a este possível encontro entre a ficçáo de Rosa e o ensaio poético de Glissant.

\section{Espelhos em face, opacidades sobrepostas}

Se, segundo Gagnebin, o "movimento auto-reflexivo da filosofia sobre seu caráter de linguagem” permite uma percepção mais aguda de suas singularidades e estratégias ${ }^{27}$, tal movimento na literatura eleva-se ao quadrado, especialmente quando falamos de Grande sertão: veredas, ficção que, no jogo e ato da ficcionalização, discute e lança mão de diversos aspectos do uso da linguagem, inclusive nos processos de construção e apreensão do "real". Segundo João Adolfo Hansen,

\footnotetext{
25 Idem, p. 208.

26 Idem, p. 209

27 Idem, p. 204.
} 
Rosa tem a imaginação de um homem de teatro que se recusasse a representar fatos, coisas, açóes, objetos do movimento e que efetuasse o movimento mesmo, sempre aquém ou além da representação, escorrendo além dos lados da moldura, sem forma e estilo adequados, interpostos entre o objeto designado e o movimento efetuado. [...] A linguagem de Rosa é operada pela diferença: reescreve a língua, além e aquém da estória narrada; ficção da ficção, pois, em que a literatura de ficção é a ficção da literatura, exploração de um campo de falas já anônimas que, no efeito de deslocamento, encenam o inexpresso do sentido. ${ }^{28}$

Reversão feita, irreversivelmente então a "literatura de ficção" torna-se "ficção de literatura", pois dá-se como avaliação crítica da forma na própria forma, representação e avaliação simultâneas. A narração tateante de Riobaldo gera no leitor um movimento pendular entre proximidade e distanciamento em relação ao texto e esta oscilação provoca a conscientização sobre o caráter de constructo do discurso, fazendo surgir a possibilidade de interpretar esta ficção como crítica da representação e de sua mediação pela linguagem - mediação contemplada e discutida não apenas na lida humana com o mundo, mas no relacionamento inter-humano na analogia sobreposta entre contar e escrever, escutar e ler. A tematização da interpretação está colocada desde o início do romance:

- Nonada. Tiros que o senhor ouviu foram de briga de homem não, Deus esteja. Alvejei mira em árvore, no quintal, no baixo do córrego. Por meu acerto. Todo dia isso faço, gosto; desde mal em minha mocidade. Daí, vieram me chamar. Causa dum bezerro: um bezerro branco, erroso, os olhos de nem ser - se viu -; e com máscara de cachorro. Me disseram; eu não quis avistar. Mesmo que, por defeito como nasceu, arrebitado de beiços, esse figurava rindo feito pessoa. Cara de gente, cara de cão: determinaram - era o demo. Povo prascóvio. Mataram.

28 HANSEN, J. A. O o: a ficção da literatura em Grande sertão: veredas. São Paulo: Hedra, 2000, p. $186-7$. 
Dono dele nem sei quem for. Vieram emprestar minhas armas, cedi. Não tenho abusôes. O senhor ri certas risadas... Olhe: quando é tiro de verdade, primeiro a cachorrada pega a latir, instantaneamente - depois, então, se vai ver se deu mortos. O senhor tolere, isto é o sertão. ${ }^{29}$

Os indícios são de que o interlocutor preocupou-se com a natureza dos tiros escutados pouco antes de se encontrar com o narrador e, assim que possível, perguntou sobre, sendo a resposta de Riobaldo a esta pergunta ("Nonada") o princípio da narração. A diferença entre os tiros de exercício ("alvej[ar] mira em árvore": ficção) e os "de verdade" (quando em batalha, para matar: realidade) escapa ao visitante de Riobaldo e este sente a necessidade de explicá-la, em que se introduzem, juntamente à questão da interpretação, os temas da aparência, da violência e do diabo. Sobre este aspecto desdobrado de sua literatura, na ocasião de sua entrevista com Günter W. Lorenz em janeiro de 1965, Rosa diz ser

um contista de contos críticos. Meus romances e ciclos de romances são na realidade contos nos quais se unem a ficção poética e a realidade. Sei que daí pode facilmente nascer um filho ilegítimo, mas justamente o autor deve ter um aparelho de controle: sua cabeça. ${ }^{30}$

Podemos entender este "aparelho de controle" do autor como o cálculo poético consciente no trabalho sobre a expressão para a construção do efeito na leitura. Na mesma entrevista, o escritor ataca diversos sistemas de pensamento relacionados direta ou indiretamente a perspectivas limitadas e/ou limitadoras no uso da linguagem. Da "linguagem corrente" ao "método científico", Rosa contesta as potencialidades de tais sistemas pela constatação do aniquilamento da dimensão poética da linguagem e do pensamento, algo diretamente ligado à limitação da liberdade de invenção e, consequentemente, da diversidade de perspectivas sobre a experiência humana.

29 ROSA, J. G. Grande sertão: veredas, op. cit., p. 9.

30 ROSA, J. G. "Literatura e vida”. Arte em revista, ano I, 2: 5-17, São Paulo, mai./ago. 1979 , p. 8. 
Neste sentido, é possível estender esta reivindicação de liberdade no uso da linguagem à correspondência entre ato e expressão. Segundo Rosa, “a linguagem e a vida são uma coisa só. [...] Isto significa que, como escritor, devo me prestar contas de cada palavra e considerar cada palavra o tempo necessário até ela ser novamente vida" ${ }^{31}$. Ao se vincular vida e linguagem, ato e expressão, provoca-se em última análise uma autocrítica mais profunda, pois nesta articulação os dois elementos agem um sobre o outro, estimulando a reformulação constante de ambos e do imaginário.

Obviamente a simples alegação de posicionamentos e procedimentos por parte do autor não os coloca automaticamente em sua produção (pois como comenta Hansen, esta entrevista seria uma "oportunidade para um escrito sobre o teatro das intençôes" ${ }^{32}$ ), mas indicam preocupação e perspectiva de sua escrita.

Para Rosa, os "pensamentos de sistema”, denominação retomada de Glissant, em sua preocupação em tornar "lógicas" a realidade e a linguagem, faz-nos ilusoriamente tomar a "realidade" como um bem comum, transparente e plenamente compartilhado, de natureza única e esgotável. E isto apesar de tantas disputas pelo poder de sua definição, o que é por certo e no mínimo irônico. Sobre a oposição de Rosa a estas posturas, Hansen afirma:

Falando por paradoxos - e insistindo no valor deles em oposição ao lógico em seus livros - Rosa insiste em que seu discurso, como prática e efeito, visa a deslocar continuamente os limites explícitos da linguagem estabelecida e, subordinando sempre o que diz à maneira como diz, mostra que opera com decisóes e não como adequação a verdades já constituídas. ${ }^{33}$

Assim, temos aí seu principal aspecto político, a decisão pela exploração da potência poética da linguagem das realidades humanas resultando no que imagino como espelhos postos face a face, gerando a imagem do infinito feito do nada, como Hansen observa nos signos inicial e final de Grande sertão:

31 Idem, p. 12.

32 HANSEN, J. A. “A imaginação do paradoxo". Arte em revista, ano I, 2: 19, São Paulo, mai./ ago. 1979 , p. 19.

33 Idem, p. 19. 
veredas: "Nonada" e " $\infty$ "34. Mas também como opacidades sobrepostas, pois a linguagem, como mediadora, não é o humano que a enuncia nem a coisa que designa, é código perturbável e opaco pois desvia o que media, ainda mais quando trata de si mesmo, repetindo: opacidades sobrepostas. Estas características não poderiam ser encontradas na chamada "linguagem corrente", considerada pelo escritor "um monstro morto" por "expressa[r] apenas clichês e não idéias". ${ }^{35}$

Na escrita de Rosa, muitas são suas opções, distanciadas de purismos: “[...] enquanto vou escrevendo, eu traduzo, extraio de muitos outros idiomas. Disso resultam meus livros, escritos em um idioma próprio, meu, e pode-se deduzir daí que não me submeto à tirania da gramática e dos dicionários dos outros."36

Desenha-se um contexto em que o escritor vinculará uma espécie de engajamento contra estes sistemas à renovaçáo da linguagem literária para reforjar ou recuperar a potencialidade e diversidade poética da expressão humana. Recuperar e reforjar porque Guimarães Rosa procura realizar esta renovação dirigindo seu esforço ao passado e ao futuro, pois tanto quer inverter o empobrecimento sofrido pela língua em seu uso cotidiano, como quer inventar, de fato criar novos significados e significantes. Não se trata da criação de um novo sistema, mas da abertura e multiplicação de possibilidades da linguagem existente; não se trata da criação de novos padrões, mas da abolição de regras prescritivas em favor da flexibilidade poética da expressão. Dentre seus métodos e elementos utilizados, estão a insubmissão às normatizações alheias, a atenção dada a cada palavra, o aporte de outros idiomas e o uso de neologismos e arcaísmos, "[...] e assim nasce então meu idioma que, quero deixar bem claro, está fundido com elementos que não são de minha propriedade particular, que são acessíveis igualmente para todos os outros"37.

A declaração da disponibilidade destes elementos para todos vem novamente trazer uma perspectiva anárquica e afirmativa. Não apenas inventando, mas reprocessando estes elementos, como, segundo Rosa, qualquer um poderia fazer, deslocam-se funçóes e estruturas originais causando estranhamento e reavaliação. Apelidado de "revolucionário" por criar um "idioma próprio"

34 HANSEN, J. A. O o: a ficção da literatura em Grande sertão: veredas, op. cit.

35 ROSA, J. G. "Literatura e vida", op. cit., p. 14.

36 Idem, p. 8.

37 Idem, p. 12. 
quando julgado pelas aparências, Rosa afirma preferir ser chamado de "reacionário da língua" 38 , pois traduziria melhor a sua busca - idealizada, deve-se dizer - do sentido original da palavra.

É interessante pensar por que razão sob a aparência desta "revolução" estaria melhor colocado um "reacionarismo". Citar a busca pelo sentido original da palavra é uma parte da resposta, e mesmo sua principal, mas isto pode ser aprofundado diante do contexto de limitaçóes colocadas pelos "pensamentos de sistema".

Como já dito, sua escrita não propóe um novo sistema ou revezamento e substituiçẫo dos lugares de poder de um estado de coisas vigente. Ela é mais ambiciosa do que isto. Segundo Hansen, "sua produção desborda as fronteiras preestabelecidas da designação/significação lingüísticas, efetuando um acontecimento puro como invenção de um outro" 39 , ou seja, dá-se na (re)afirmação da língua como produtora. Tal propriedade não é essencialmente novidade se pensarmos, mesmo de modo figurativo ou idealizado, na gênese e evolução de qualquer língua. E aqui a atitude reacionária é metaforicamente a mais radical e desconstrutora, pois quer reavivar as virtualidades da língua. E então, num jogo de conversôes, poderíamos dizê-las rizomáticas, num estágio anterior ao de raiz, ausente a tomada de poder por qualquer entidade centralizadora.

Esta centralizaçáo, efetuada por tantos narradores da produçáo regionalista brasileira, para citar exemplo mais próximo a Rosa, é problematizada em Grande sertão: veredas. Riobaldo quer exercê-la, mas não tem sucesso diante do desafio e acaba por jogar com isto no texto, animado por dinâmicas da oralidade incorporadas na escrita do autor. Ainda no início do romance, tateando e avaliando a própria narração, Riobaldo testa a escuta de seu interlocutor e a nossa leitura: "Ai, arre, mas: que esta minha boca não tem ordem nenhuma. Estou contando fora, coisas divagadas. No senhor me fio? Até-que, até-que. Diga o anjo-da-guarda...”. ${ }^{40}$

A pergunta provoca o leitor: poder ou náo fiar-se na escuta/leitura, na interpretação a que estarão sujeitas suas palavras, é uma das principais questóes para Riobaldo, assim como a interpretaçáo que ele mesmo procura efetuar ali.

\footnotetext{
38 Idem, p.13.

39 HANSEN, J. A. "A imaginação do paradoxo", op. cit., p. 19.

40 ROSA, J. G. Grande sertão: veredas, op. cit., p. 19, realce meu.
} 
Rejeita-se então qualquer possibilidade de uso ingênuo da expressão, tanto por Rosa, como por seu narrador. Mais à frente, ainda sobre a narração, afirma o de que antes se desculpou, a falta de ordem, e a relaciona à memória:

Sei que estou contando errado, pelos altos. Desemendo. Mas não é por disfarçar, não pense. De grave, na lei do comum, disse ao senhor quase tudo. Náo crio receio. O senhor é homem de pensar o dos outros como sendo o seu, náo é criatura de pôr denúncia. E meus feitos já revogaram, prescrição dita. Tenho meu respeito firmado. Agora, sou anta empoçada, ninguém me caça. Da vida pouco me resta - só o deo-gratias; e o troco. Bobéia. [...] Eu estou contando assim, porque é o meu jeito de contar. Guerras e batalhas? Isso é como jogo de baralho, verte, reverte. [...] A lembrança da vida da gente se guarda em trechos diversos, cada um com seu signo e sentimento, uns com os outros acho que nem náo misturam. Contar seguido, alinhavado, só mesmo sendo as coisas de rasa importância. De cada vivimento que eu real tive, de alegria forte ou pesar, cada vez daquela hoje vejo que eu era como se fosse diferente pessoa. Sucedido desgovernado. Assim eu acho, assim é que eu conto. O senhor é bondoso de me ouvir. Tem horas antigas que ficaram muito mais perto da gente do que outras, de recente data. O senhor mesmo sabe. ${ }^{41}$

Riobaldo diz expressar-se assim pela intimidade que vê entre ato, como fato de entendimento/perspectiva, e expressão: "Assim eu acho, assim é que eu conto". E a escuta é sempre requisitada na crescente cumplicidade à medida que o texto avança. Mas a aceitação por Riobaldo da opacidade de sua memória e de tudo o que procura ordenar e significar, por conta mesmo desta atitude, continua não sendo ponto pacífico:

Sempre sei, realmente. Só o que eu quis, todo o tempo, o que eu pelejei para achar, era uma só coisa - a inteira - cujo significado

${ }^{41}$ Idem, p. 77-8, realce meu. 
e vislumbrado dela eu vejo que sempre tive. A que era: que existe uma receita, a norma dum caminho certo, estreito, de cada uma pessoa viver - e essa pauta cada um tem - mas a gente mesmo, no comum, não sabe encontrar; como é que, sozinho, por si, alguém ia poder encontrar e saber? Mas, esse norteado, tem. Tem que ter. Se não, a vida de todos ficava sendo sempre o confuso dessa doideira que é. E que: para cada dia, e cada hora, só uma ação possível da gente é que consegue ser a certa. Aquilo está no encoberto; mas, fora dessa conseqüência, tudo o que eu fizer, o que o senhor fizer, o que o beltrano fizer, o que todo-o-mundo fizer, ou deixar de fazer, fica sendo falso, e é o errado. Ah, porque aquela outra é a lei, escondida e vivível mas não achável, do verdadeiro viver: que para cada pessoa, sua continuação, já foi projetada, como o que se póe, em teatro, para cada representador - sua parte, que antes já foi inventada, num papel... ${ }^{42}$

Neste discorrer paradoxal do narrador, essa "receita" do viver existiria ao mesmo tempo em que estaria encoberta, "vivível mas não achável”, como se fôssemos atores inconscientes de nossa própria atuação e roteiro, sempre tateando a sequência dos acontecimentos. Dada a distância da narração em relação ao narrado, Riobaldo vê tudo como história, passado reordenado no presente, e desestabiliza qualquer verdade e sua possibilidade no ato mesmo de afirmar a necessidade da tal norma "de cada uma pessoa viver" diante do "confuso dessa doideira" da vida: "Tem que ter" "esse norteado". Então recorre à representação, à ficção como simulação do real, ciente de sua natureza de invenção, quando compara a necessidade desta referência a um roteiro teatral onde tudo estaria predefinido.

Mais paradoxais e fluidos se tornam estes comentários de Riobaldo quando se notam outras definiçóes do viver em que seu principal sinônimo é travessia, passagem, caracterização menos relutante na incorporação do elemento de imprevisibilidade, e que domina o romance:

Ah, tem uma repetição, que sempre outras vezes em minha vida acontece. Eu atravesso as coisas - e no meio da travessia

42 Idem, p. 366. 
não vejo! - só estava era entretido na idéia dos lugares de saída e de chegada. Assaz o senhor sabe: a gente quer passar um rio a nado, e passa; mas vai dar na outra banda é num ponto muito mais embaixo, bem diverso do em que primeiro se pensou. Viver nem não é muito perigoso? ${ }^{43}$

Por que era que eu estava procedendo à-toa assim? Senhor, sei? O senhor vá pondo seu perceber. A gente vive repetido, o repetido, e, escorregável, num mim minuto, já está empurrado noutro galho. Acertasse eu com o que depois sabendo fiquei, para de lá de tantos assombros... Um está sempre no escuro, só no último derradeiro é que clareiam a sala. Digo: o real não está na saída nem na chegada: ele se dispõe para a gente é no meio da travessia. ${ }^{44}$

Amável o senhor me ouviu, minha idéia confirmou: que o Diabo não existe. Pois não? O senhor é um homem soberano, circunspecto. Amigos somos. Nonada. O diabo não há! É o que eu digo, se for... Existe é homem humano. Travessia. $\infty{ }^{45}$

Ao lado da afirmação do modo de discurso, coloca-se esta definição de vida, ambas baseadas na reflexão sobre a ilusão e efemeridade de pontos de partida e chegada. Tal propriedade no discurso expressa-se como tateamento, acumulação e multiplicidade de conexôes internas e externas e distancia-se da narrativa dissecatória que se tem como superior a seu objeto.

\section{Encontros}

"Travessia", última palavra do romance, e “ $\infty$ ", último símbolo gráfico, parecem ser a sugestão para a releitura de Grande sertão: veredas ou, tomando-os como linhas de fuga, a sugestão para a releitura de nosso próprio imaginá-

\footnotetext{
43 Idem, p. 30, realce meu.

44 Idem, p. 51-2, realce meu.

45 Idem, p. 460, realce meu.
} 
rio; e assim não terminam. São índices importantes, entre outros elementos, por evidenciar e amplificar as relações entre texto e leitor, narrador e seu interlocutor. Para adentrar estas relaçôes, basta perguntar quem enuncia o " $\infty$ ”? Ícone não-verbal, existe apenas visualmente, escrito, no entanto está ao final de uma ficcionalização da fala, e aí contrasta. O símbolo tensiona em sua apresentação gráfica uma tradução visual - fora e dentro da escrita - do conceito "infinito", colocando-se como síntese espacial, entre sentido e palavra: uma linha que vai, volta e se emenda em si mesma é a paradoxal representação do que não tem fim. Paradoxal também e basicamente porque carrega a opacidade de toda mediação, apesar de pretender-se transparente.

A linha emendada em si mesma pode ser ou não a mesma a cada retomada, caracterizando o sem-fim como adjetivo de algo, ou, como nome, a representação do que não se emenda a nada, nem a si mesmo, e apenas avança. Nestes sentidos, o ícone e seus desdobramentos poderiam ser vistos como uma concorrência das posturas do Mesmo e do Diverso, oposição formulada por Glissant, correlatas respectivamente à saturação de um ciclo vicioso e a um percurso sem objetivo final, limite ou fronteira. A inscrição do ícone, respondendo à pergunta colocada mais acima, é feita pelo autor que, ao deslizá-lo como contraste e prolongamento, como uma confissão de seu trabalho produtivo, potencializa a experimentada vertigem do leitor durante a travessia do texto-rizoma de centenas de páginas repletas de linhas de fuga.

Tais proposiçóes são motivadas pelas decisôes constitutivas da literatura ficcional de Rosa, em Grande sertão: veredas, e ensaística de Glissant. Não fosse o narrar rizomático de Riobaldo, o " $\infty$ ” não estaria assim carregado; não fosse o ensaio poético de Glissant em si mesmo expressão dada ao Diverso, encenando em suas linhas e entrelinhas a Relação, não demonstraria a obsolescência do Mesmo.

Suas produçóes encontram-se porque flexibilizam e desdobram ensaio e ficção, um em direção ao que seriam características do outro. Édouard Glissant dota seus ensaios de uma proposta poética e filosófica que náo procura o esmiuçamento sistematizado e Guimarães Rosa desdobra o narrar de Riobaldo em metaliteratura. Ambos quebram supostos pactos de leitura em seus gêneros ao desestabilizá-los. A partir disto, e paralelamente como procedimentos, diversos outros aspectos confluem. 
Procedem à utilização de aspectos da oralidade por constatarem a banalização - segundo Rosa - e a violência - segundo Glissant - da língua dita culta e padrão, pelo que acabam produzindo um discurso do entre-lugar. Elemento periférico, a oralidade é utilizada por Rosa para revitalizar a língua saturada de clichês e esvaziada de sentido; Glissant procura uma nova audiência da voz literária através desta contaminação. Ambos procedem assim à desierarquização da relação entre elementos centrais e periféricos em diversos níveis. Sobre este aspecto em Rosa, afirma Marli Fantini:

Ao descentrar as fronteiras hierárquicas que imobilizam, em pólos inconciliáveis, o centro e a periferia, o arcaico e o moderno, a oralidade e a escritura, Guimarães Rosa assume uma posição desconstrutora contra toda forma de demarcação cultural fixa e totalizante. ${ }^{46}$

Nesta irrigação pela oralidade está não apenas o uso de seus elementos, mas principalmente a prática de sua dinâmica como aproximação tateante $\mathrm{e}$ reelaboração não dissimulada do pensamento ou narrativa valorizando as articulaçóes poéticas. Ao lado disto também os gêneros se contaminam da flexibilidade da oralidade. Como exemplo em Glissant, diz Marielle Anselmo sobre Philosophie de la Relation ${ }^{47}$ : "sous-titré non sans incidence 'poésie en étendue', [c'] est un livre protéiforme, véritablement un 'archipel' de langages, qui voit s'entrecroiser essai, récit autobiographique et poème: un essai philosophicopoétique" 48 ; e a isto acrescenta, utilizando-se de uma imagem oportuna: "un cheval de Troie dans la langue française - qui, la faisant tournoyer, la perd et se perd avec elle". 49

46 FANTINI, M. Guimarães Rosa - Fronteiras, Margens, Passagens. São Paulo: Senac; Cotia: Ateliê, 2003, p. 59.

47 GLISSANT, É. Philosophie de la relation. Paris: Gallimard, 2009.

48 “subintitulado, não sem incidência, 'poesia em extensão', é um livro proteiforme, verdadeiramente um 'arquipélago' de linguagens, que se vê entrecruzado por ensaio, texto autobiográfico e poema: um ensaio filosófico-poético". ANSELMO, M. "Le monde en d'autres langues”. Nonfiction, 2009. Disponível em http://www.nonfiction.fr/article-2629-le_ monde_en_dautres_langues.htm. Acesso em 10/12/2010.

49 "um cavalo de Troia na língua francesa - que, fazendo-a revirar-se, perde-a e se perde com ela”. Idem. 
O princípio é de imbricamento, ao que dicotomias analíticas não bastam, mas são frequentemente necessárias e tentam desenhar justamente este entre-lugar do contato. A ideia de imbricamento traz a crioulização e o pensamento do vestígio: acumulação e esforço de reinvenção por memórias irreconhecíveis, restos de morte, restos de vida. Notados como processos, não necessariamente inconscientes, mas copiados e definidos pela análise, e adotados conscientemente como resistência aos sistemas de pensamento, a partir deles Glissant elabora a postura do Diverso e sua predisposição à Relação como filosofia ou poética flexibilíssimas cujo único requisito é o diálogo, a própria Relação, impalpável e apenas possível quando há mais que um - ou mesmo sua dissolução conceitual: multiplicidade.

À maneira do discurso em espiral de Glissant, o narrador Riobaldo tece uma rede narrativa contando e retomando acontecimentos, reelaborando julgamentos, trabalhando a memória numa acumulação traduzida formalmente no texto contínuo e virtualmente inesgotável, já que cada retorno a ele, na interatividade da leitura, move o sentido.

Rosa parte da valorização da flexibilidade que vê no português brasileiro e angaria outros elementos e processos de outras variantes do português, de outras línguas. Como Glissant que afirma "J'écris en présence de toutes les langues du monde" ${ }^{50}$, Rosa provocativamente simula e dissimula a construção de sentido de que o leitor disposto participa, chamado para o embrenhamento no texto. Assim, o "escrever em presença de todas as línguas do mundo" refere-se à postura e à perspectiva de enunciação abertas, ao fato de que as línguas incluindo as maternas e mesmo que não se fale outra - representam expressóes de opacidades que podem colocar-se em relação.

Hino de humor e amor às diferenças, a grande arte de Guimarães Rosa deborda o restrito âmbito de literatura regional, ou de sua dimensão de "belas artes", para abranger a pluralidade e a complexidade de práticas culturais e lingüísticas que concorreram para a formação do "Novo Mundo". No seu processo de

50 "Eu escrevo em presença de todas as línguas do mundo". GLISSANT, É. Philosophie de la relation, op. cit., p. 80. Cf. igualmente GLISSANT, É. Introduction à une Poétique du Divers, Montréal: Presses de l'Université de Montréal, 1995, p. 90-1 e/ou GLISSANT, É. Introdução a uma Poética da Diversidade, op. cit., p. 144 (edição brasileira). 
mesclar e relativizar pólos dicotomizados, Rosa problematiza os critérios hegemônicos e excludentes herdados de uma concepção historiográfica hierarquizante, cujo continuum linear e vazio, seja através de arsenais bélicos, seja através da correção estética ou através da cosmovisão carnavalesca, ele faz saltar pelos ares. ${ }^{51}$

Distantes da postura tão frequente nos que versam sobre a "realidade" pretendendo dominá-la, os autores aqui abordados antes de tudo demoram-se na escuta das histórias e humanidades ignoradas pela História. Estas impregnam seus textos e constituem neles uma constelação de relaçóes transversais sem pretensão a transcendência de valores. A atitude poética e a liberdade na renovação da linguagem é a liberdade na renovação da relação com o "real". Nesta afirmação política reside a renúncia a universalismos por um lado e, por outro, a regionalismos, pelo fechamento das linhas de fuga que estes representam.

\section{Despacto, desencontro}

Mas esta aproximação é operação de um terceiro: este que escreve. É então necessária a consideração da desconstrução, a exemplo dos autores estudados: é desencontro, pois não se encontram por si. A encenação da aproximação faz-se também para ver que, apesar de aproximáveis, não deixam de estar distantes apenas como anti-sistemas que se entreolham e seguem seus devires, "devir a não se entender como vir-a-ser, não havendo ser, nem nada que a ele leve". 52

Se é necessário desconstruir a ilusão do encontro no desencontro, também não há pacto possível com o que não se estabiliza, sendo antes o pacto com o Diabo de Riobaldo a contra-efetuação do pacto com Deus, metáfora do Uno:

51 FANTINI, M. Guimarães Rosa-Fronteiras, Margens, Passagens, op. cit., p. 227.

52 KOSSOVITCH, L. Prefácio. HANSEN, J. A. O o: a ficção da literatura em Grande sertão: veredas, op. cit., p. 8. 
Como na narração Riobaldo identifica Deus e ser, o (não)-ser do Diabo está dominado por seu valor: não é seu oposto, como o maniqueísmo poderia fazer supor, mas um de seus gêneros, também nomeado "O Outro" 53 [...]. Tal outro confunde-se com a linguagem mesma, pois é nela que Riobaldo se investe como um Eu para Si, organizando o Si e o Real como representação imaginária da relação com o Outro: o pacto com o Diabo, enquanto transgressão pela qual se introduz um outro, significa transgressão do discurso e, simultaneamente, uma figuração sempre móvel, evanescente e ressurgente, alteraçáo no discurso. $^{54}$

Recordemos as "oposiçôes" de imagens e metáforas: raiz e rizoma, transparência e opacidade, Deus e Diabo, Mesmo e Diverso. À elevação do Mesmo forçando transparência e redução, de Deus exercendo a univocidade em onisciência e onipotência e ao aprofundamento da raiz centralizando-se e estabelecendo a fixidez de funçóes reagem a corrosão do Diabo, a multiplicidade do rizoma e a Relação transversal do Diverso. Reiterando o dito anteriormente para o relacionamento com as opacidades e na oposiçáo rizoma-raiz, não se trata da simples inversão de valores na manutenção da mesma forma, mas de sua trituração.

Anarquizadas as hierarquias, demonstra-se construção e desconstrução de ficções de realidade e realidades de ficção, de discursos que tendem sempre a recortar e esquadrinhar o tecido político-linguístico. Aí os termos "anarquia" e "desierarquização" são em algum sentido inadequados pois negam ou desfazem "arquia" e "hierarquia" como se fossem, estes movimentos de negação, posteriores. São todavia simultâneos, solventes frágeis da fragilidade dos sistemas; denunciam sua efemeridade e pretensóes tanto reacionárias como revolucionárias, um ciclo vicioso de sistemas deglutindo sistemas.

53 ROSA, J. G. Grande sertão: veredas, op. cit., p. 229.

54 HANSEN, J. A. O o: a fiç̧ão da literatura em Grande sertão: veredas, op. cit., p. 91-2. 


\title{
ÉDOUARD GLISSANT ET JOÃO GUIMARÃES ROSA: RENCONTRE D'ÉCRITURES, LIGNES DE FUITE
}

\author{
RÉSUMÉ \\ Il s'agit ici d'un rapprochement entre des notions dé- \\ veloppées par le philosophe martiniquais Édouard \\ Glissant (1928-2011) dans certains essais et le roman \\ Grande sertão: veredas (1956) de João Guimarães Rosa \\ (1908-1967), écrivain brésilien. J'ai prétendu identifier \\ des résonances entre ses écritures en considérant les fui- \\ tes de leurs genres "originels", roman et essai, et com- \\ ment ils imbriquent l'éthique et l'esthétique. \\ MOTS-CLÉS: Édouard Glissant, João Guimarães Rosa, \\ poétiques d'écriture.
}

Recebido em: 21/03/12

Aprovado em: 27/11/12 